\title{
Microwave-assisted synthesis of novel amide based chiral tripodal receptors for recognition of cation and anion sensors
}

\author{
Sevil S. Azizoglu, Seref Kaplan, Gulsen Ozturk, Yilmaz Turgut* and Mahmut Togrul* \\ University of Dicle, Faculty of Science, Department of Chemistry, 21280, Diyarbakir, Turkey \\ E-mail.togrularya@gmail.com;.yturgut@dicle.edu.tr
}

DOI: http://dx.doi.org/10.3998/ark.5550190.p009.434

\begin{abstract}
Five novel amide based chiral tripodal receptors were synthesized under microwave irradiation by reacting nitrilotriacetic acid with chiral amino alcohols in a solvent-free medium with high yields $(\geq 90 \%$ ). The recognition affinities of these tripodal receptors were investigated towards anions and chiral organic ammonium cations using ${ }^{1} \mathrm{H}$ NMR titration method. The results show that receptor 1 displays more affinity against anions compared with other receptors and the tripodal receptor 4 demonstrated a significant enantiomeric selectivity towards the $(R)$ naphthylethylammonium perchlorate (ERF 54\%).
\end{abstract}

Keywords: Tripodal receptor, cation sensor, anion sensor, microwave and NMR titration

\section{Introduction}

Selective recognition of cations and anions by artificial receptors has been an attractive research area for their potentials in various applications such as biochemical and pharmaceutical studies, separation processes and sensing. ${ }^{1-6}$ Multiple interactions between hosts and guests are necessary in developing an artificial receptor exhibiting selectivity towards a specific analyst. Tripodal based

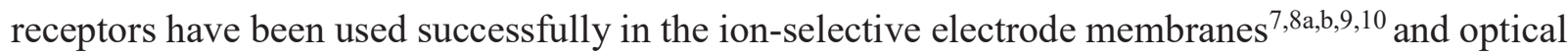
sensors. ${ }^{11-14}$ They allow three arms as interacting sites for ligands. Molecular design allows controlling binding properties such as selectivity, stability and complexation. Selectivity of a tripodal receptor largely depends on cavity size and rigidity of the arms ${ }^{15-17}$ and therefore, they are known to have several advantages compared to monopodal and bipodal receptors: i) they usually bind metal ions very strongly due to increasing chelating influence, ii) bulkiness of tripodal ligands allows them to be more reactive towards metal ions. Because of the distinctive features of synthetic tripodal receptor system, their design and development is a very active field of study in the supramolecular chemistry. ${ }^{6,7,18,19}$ An amide functional group, which exists in the structure of many synthetic materials, is very important in the organic chemistry and biochemistry. Therefore, the 
synthesis of compounds containing amide functionality is of interest in synthetic chemistry. The use of microwave technology in organic chemistry was widely investigated in the last decade and hence a great number of papers report that many chemical transformations can be carried out successfully by this technique. ${ }^{20}$ It significantly reduces reaction time and thus provides high yield, less by-product formation as well as easier workup consistent with green chemistry, solvent free organic conversion, atom economy and selective reaction. ${ }^{21,22-29}$ Therefore, the synthesis of tripodal receptors based on amide formation has been carried out by condensation of carboxylic acids and amines, employing microwave technique which allows direct conversion of carboxylic acids to amides. Otherwise, the conversions of carboxylic acids to more reactive intermediate are necessary to obtain amides.

This paper involves the synthesis of a series of novel tripodal receptors based on amides under microwave conditions and the evaluation of their molecular recognition abilities towards various anions $\left(\mathrm{H}_{2} \mathrm{PO}_{4}^{-}, \mathrm{HSO}_{4}^{-}, \mathrm{C}_{6} \mathrm{H}_{5} \mathrm{CO}_{2}^{-}, \mathrm{CH}_{3} \mathrm{CO}_{2}^{-}, \mathrm{F}^{-}, \mathrm{Cl}^{-}, \mathrm{Br}^{-}\right)$and chiral organic ammonium cations using ${ }^{1} \mathrm{H}$ NMR titration methods.

\section{Results and discussion}

\section{Synthesis}

In this study, five amide-based tripodal receptors were synthesized under microwave irradiation (Scheme 1) and their binding affinities were examined against various anion salts of tetrabutylammonium (TBA) $\left(\mathrm{H}_{2} \mathrm{PO}_{4}^{-}, \mathrm{HSO}_{4}^{-}, \mathrm{C}_{6} \mathrm{H}_{5} \mathrm{CO}_{2}^{-}, \mathrm{CH}_{3} \mathrm{CO}_{2}^{-}, \mathrm{F}^{-}, \mathrm{Cl}^{-}, \mathrm{Br}^{-}\right)$and chiral organic cation salts of ammonium by ${ }^{1} \mathrm{H}$ NMR titration method. The reason for employing anions as TBA salts was due to their higher solubility in organic solvents compared with that of their alkali metals salts. The structures of receptors were elucidated by IR, ${ }^{1} \mathrm{H}$ NMR, ${ }^{13} \mathrm{C}$ NMR, DEPT, 2D NMR (COSY, HMQC) and mass spectroscopy. The reactions were performed using microwave irradiation conditions under atmospheric pressure with $1000 \mathrm{~W}$ at $150^{\circ} \mathrm{C}$, maximum 42 minutes (generally 2-3 drops of water was added). All amides were obtained with very high yields ( $\geq 90 \%)$ (Scheme 1) and products were purified without applying expensive methods such as chromatography. 


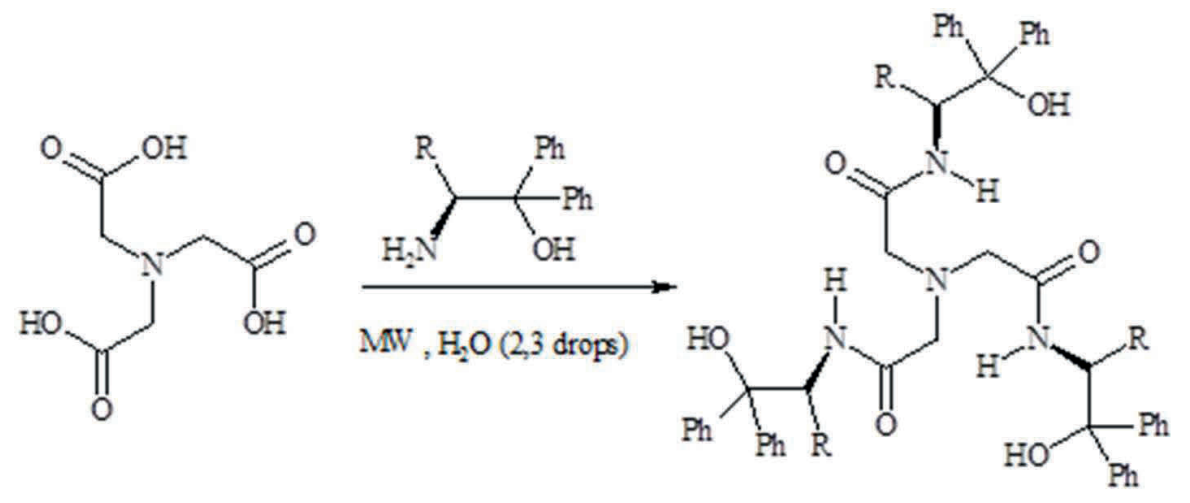

R:Methyl- (1), isopropyl- (2), isobutyl- (3), benzyl- (4), phenyl- (5)

Scheme 1. Synthesis of chiral tripodal receptors.

\section{Determination of Stoichiometry and Complexation Constant $\left(K_{a}\right)$}

${ }^{1} \mathrm{H}$ NMR spectra were recorded for the changes in the chemical shifts of receptors at various concentrations of the ions. A representative example is illustrated in Figure 1 for the spectra of the receptor 1 with $\mathrm{H}_{2} \mathrm{PO}_{4}^{-}$anion. It indicates that significant changes occur in the $-\mathrm{CH}$ hydrogens upon addition of the anion. A similar spectra were recorded for the complex of receptor $\mathbf{2}$ with $(S)$ phenylethylammonium as demonstrated in Figure 1.

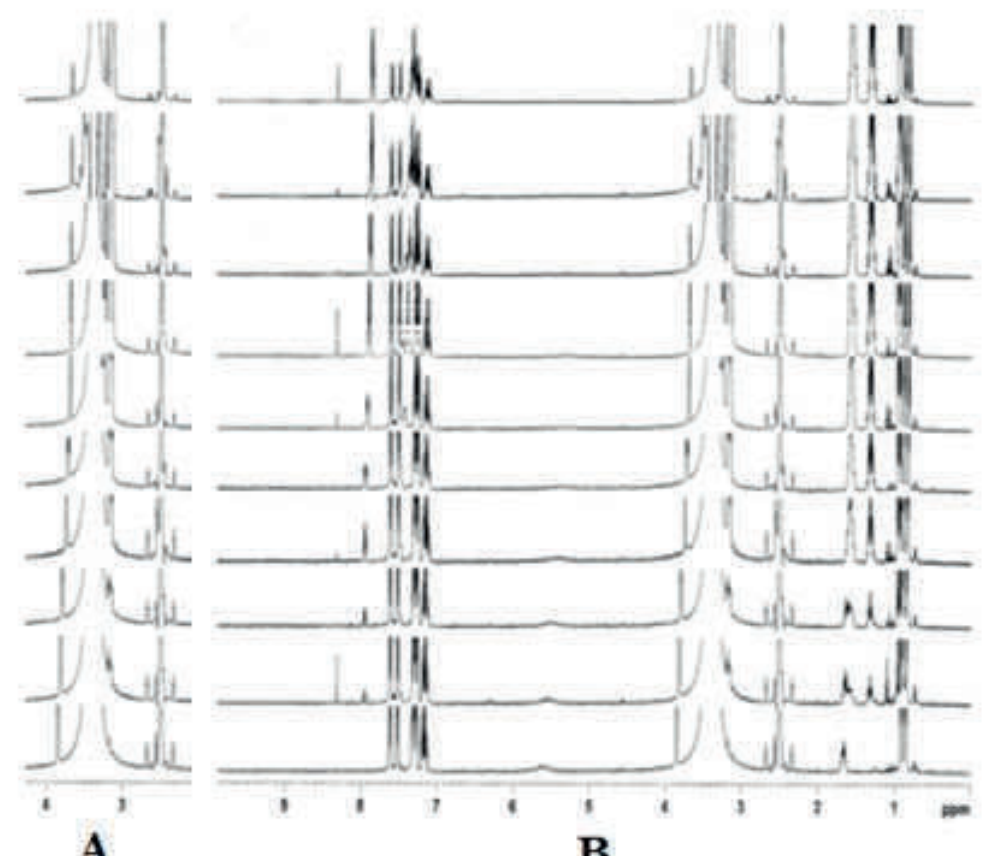

Figure 1. (B) Chemical shift in the ${ }^{1} \mathrm{H}$ NMR spectra of receptor $\mathbf{2}$ caused by addition of tetrabuthyl ammonium dihydrogen phosphate $(0.2,0.3,0.7,1.0,2.0,3.0,4.0,5.0,6.0$ fold $)$ in the presence of constant receptor $2\left(1 \times 10^{-3} \mathrm{M}\right)$. (A) Expanded part of $\mathbf{B}$ spectra between $\delta 3.60$ and $3.95 \mathrm{ppm}$. 
Determination of the stoichiometry of complexation between a receptor and a ligand is crucial to determine the binding constants of the complexes in the molecular and enantiomeric recognition studies. ${ }^{30}$ Although a variety of methods have been used for this purpose, Job Plots method has become the most frequent and routine one. A typical Job's Plot for the complex of tripodal receptor 2 with $\mathrm{H}_{2} \mathrm{PO}_{4}^{-}$anion in DMSO- $d_{6}$ shows the maximum at a molar fraction of 0.5 (Figure 2), corresponding to a 1:1 ratio. Similar results were obtained for all tripodal receptors with anions.

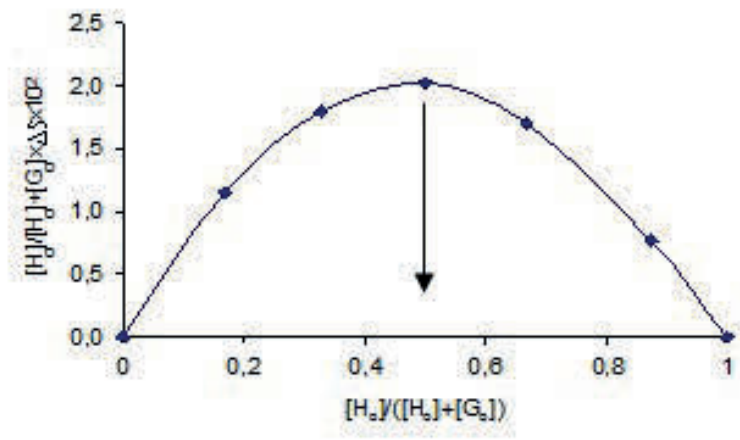

Figure 2. Job's Plots for the complex of receptor 1 with $\mathrm{H}_{2} \mathrm{PO}_{4}^{-}$.

There are many methods reported for determination of complexation constants. ${ }^{31,32}$ They are mainly graphical methods and designed computer program packages. The binding constant between receptors and ions were calculated by ${ }^{1} \mathrm{H}$ NMR titration data using non-linear curve fitting approach. Two reprehensive data are presented in Figure 3 for the complexes of receptor 2 with tetrabutylammonium benzoate (left) and $(S)$-AM1 (right).
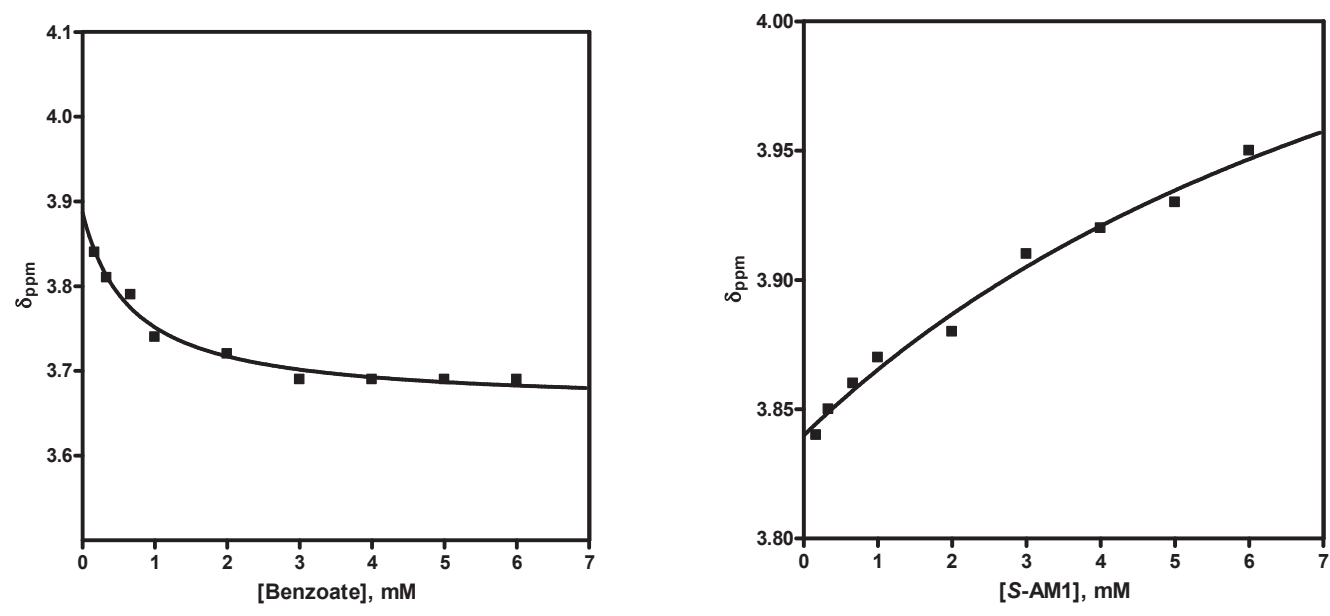

Figure 3. Chemical shifts with the $-\mathrm{CH}$ (asymmetrical methine hydrogen) in the tripodal receptors 2 against the addition of various concentrations $\left(0-6 \times 10^{-3} \mathrm{M}\right)$ of tetrabutylammonium benzoate (left) and (S)-AM1 (right) in DMSO- $d_{6}$ at $25^{\circ} \mathrm{C}$. 


\section{Anion Recognition Studies}

We have previously reported the synthesis of tripodal receptors 1 and $2 .{ }^{33}$ The selectivity trends of binding affinity of anions for tripodal receptor 1 was in order of $\mathrm{H}_{2} \mathrm{PO}_{4}^{-}>\mathrm{C}_{6} \mathrm{H}_{5} \mathrm{CO}_{2}>\mathrm{HSO}_{4}-$ and for tripodal 2 the order was $\mathrm{H}_{2} \mathrm{PO}_{4}^{-}>\mathrm{C}_{6} \mathrm{H}_{5} \mathrm{CO}_{2}>\mathrm{ClO}_{4}^{-}>\mathrm{PF}_{6}>\mathrm{HSO}_{4}{ }^{-}$in DMSO- $d_{6}$. The study clearly demonstrated that the spacer of tripodal-type receptor influences the recognition for anions.
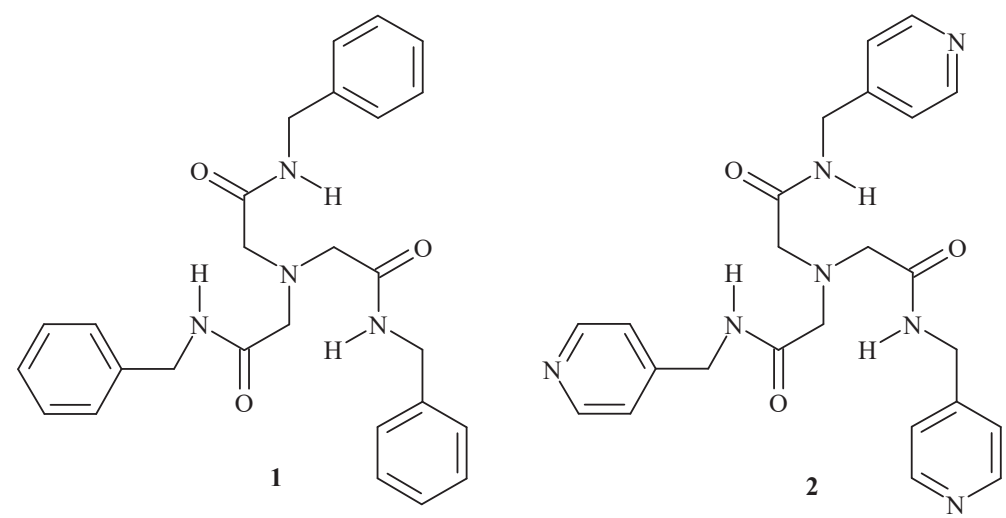

Table 1. Binding constants $\left(K_{\mathrm{a}}, \mathrm{M}^{-1}\right)$ of tripodal receptors 1-5 with various anions in DMSO- $d_{6}$ collected at $25 \pm 0.1{ }^{\circ} \mathrm{C}$

\begin{tabular}{llccccc}
\hline & & \multicolumn{5}{c}{$K_{\mathrm{a}}\left(\mathrm{M}^{-1}\right)^{* *}$} \\
\cline { 3 - 7 } Entry & Anion* & $\mathbf{1}$ & $\mathbf{2}$ & $\mathbf{3}$ & $\mathbf{4}$ & $\mathbf{5}$ \\
\hline 1 & $\mathrm{H}_{2} \mathrm{PO}_{4}^{-}$ & $511.21 \pm 1.27$ & $869.60 \pm 11.12$ & $1074.73 \pm 7.92$ & $1823.8 \pm 6.51$ & $1161.21 \pm 0.14$ \\
2 & $\mathrm{HSO}_{4}^{-}$ & nd & nd & nd & $58.61 \pm 0.02$ & nd \\
3 & $\mathrm{C}_{6} \mathrm{H}_{5} \mathrm{CO}_{2}^{-}$ & $1552.31 \pm 12.94$ & $1940.27 \pm 10.77$ & $1878.38 \pm 9.27$ & $2242.13 \pm 8.44$ & $1987.60 \pm 0.11$ \\
4 & $\mathrm{CH}_{3} \mathrm{CO}_{2}^{-}$ & $1990.01 \pm 5.77$ & $388.03 \pm 0.23$ & $1401.32 \pm 7.06$ & $1926.44 \pm 7.94$ & $1422.50 \pm 0.16$ \\
5 & $\mathrm{~F}^{-}$ & $365.23 \pm 1.67$ & $391.83 \pm 1.93$ & $519.21 \pm 4.86$ & $509.71 \pm 1.36$ & $660.50 \pm 0.55$ \\
6 & $\mathrm{Cl}^{-}$ & nd & $86.72 \pm 0.08$ & $44.71 \pm 0.02$ & nd & $262.60 \pm 1.58$ \\
7 & $\mathrm{Br}^{-}$ & $64.31 \pm 0.05$ & nd & nd & $247.7 \pm 0.12$ & nd \\
\hline
\end{tabular}

nd: Not determined; $*$ Anions were used as tetrabutylammonium salts. ${ }^{*} K_{\mathrm{a}}$ corresponds to association constants which were obtained from $1 / K_{\text {diss. }}$

Binding constants obtained for the complexes of receptors with anions are given in Table 1. They indicated that tripodal receptors have a better affinity against $\mathrm{C}_{6} \mathrm{H}_{5} \mathrm{CO}_{2}^{-}$and $\mathrm{CH}_{3} \mathrm{CO}_{2}^{-}$anions followed by $\mathrm{H}_{2} \mathrm{PO}_{4}^{-}$. However, it does not bind or weakly bind to $\mathrm{HSO}_{4}^{-}, \mathrm{Cl}^{-}$and $\mathrm{Br}^{-}$anions. It is thought that hydrogen bonds would play a key role in the recognition of these receptors with anions (Scheme 2). The main hydrogen donors are expected to be amidic hydrogens while the $\mathrm{OH}$ may be also involved in the interactions. However, we could not provide an evidence to show the involvements of these hydrogen's in the complexation since the former are overlapped by aromatic hydrogens and the presence of water impurity hampers to observe the shifts in the OH hydrogens. The better affinity of the receptors (4 and 5 ) against benzoate or acetate may be associated with the 
presence of further $\pi-\pi$ or $\pi-\mathrm{CH}$ interactions. The interaction of 4 and 5 with benzoate is thought to involve $\pi-\pi$ interactions and those with acetate via $\mathrm{CH}-\pi$ interactions since they bear aromatic ring on each arm as shown in Scheme 2. So, the reason for the better selectivity for benzoate over acetate may be attributed the favourable $\pi-\pi$ interactions compared with $\mathrm{CH}-\pi$ interactions.

Tripodal receptors showed the highest affinity for fluoride compared with chloride and bromide. This may be attributed to the fact that hydrogen bonding is the main driving forces for the complexation between the receptors and anions and hence fluoride apparently is a better donor compared with chloride and bromide. A parallel trend was also previously reported for a structurally similar systems. ${ }^{34-36}$
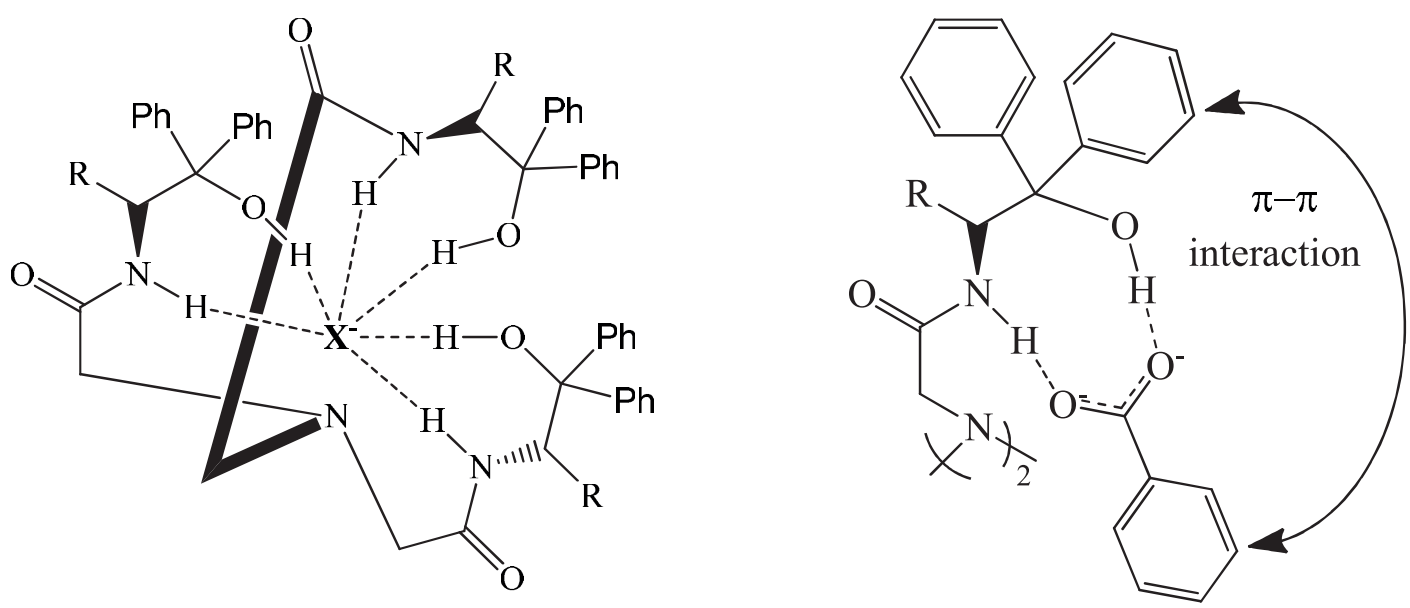

Scheme 2. (left) A general model proposed for the recognition of anions $\left(\mathrm{X}=\mathrm{H}_{2} \mathrm{PO}_{4}^{-}, \mathrm{HSO}_{4}^{-}\right.$, $\mathrm{C}_{6} \mathrm{H}_{5} \mathrm{CO}_{2}^{-}, \mathrm{CH}_{3} \mathrm{CO}_{2}^{-}, \mathrm{ClO}_{4}^{-}, \mathrm{F}^{-}, \mathrm{Cl}^{-}, \mathrm{Br}^{-}$) by receptors. (right) The possible explaination of the selectivity of benzoate by receptors.

\section{Cation Recognition}

The design of amide-based tripodals for a cation requires a receptor unit that selectively interacts with a cation. Owing to the special structure of their three flexible donor-atom-containing chains, tripodal receptors can form complexes with many organic ammonium cations and various anions. ${ }^{6}$ Enantiomeric recognition studies of amine or protonated amine salts are considerably important, because these molecules are basic building blocks of many biological materials. Since, the tripodal receptors are highly symmetric and relatively rigid due to amide moieties, they are used in the enantioselective discrimination of phenylethylammonium [(R)-AM1, $(S)$-AM1] and naphthylethylammonium $\left[(R)-\mathrm{AM} 2\right.$ and $(S)$-AM2] salts, by ${ }^{1} \mathrm{H}$ NMR titration method. During titration, the signal of $-\mathrm{CH}$ hydrogen tripodal receptors shifted to downfield with addition of the cation molecules (Figure 4). However, the shifts were in high field for the complexes with anion molecules. The possibility of simple acid-base chemistry between receptors and cations was ruled out by shifts in ${ }^{1} \mathrm{H}$ NMR spectra. It would be expected to have significant shifts in -CH signals of both receptors and cations if the proton transfer occurs.

The binding constants between the receptors (1-5) and enantiomers are presented in Table 2 . 
Data indicate that receptors generally prefer to bind $R$ enantiomers of salts, except that receptor 1 significantly prefers to bind $S$ enantiomer of AM1 with ERF of $34 \%$. On the other hand, this receptor prefers to bind $R$ enantiomer of AM2 with ERF of $36 \%$. A significant observation of this study is that receptor 4 show high discrimination against AM1 salts, which preferably bind to $R$ enantiomer with ERF of $54 \%$.

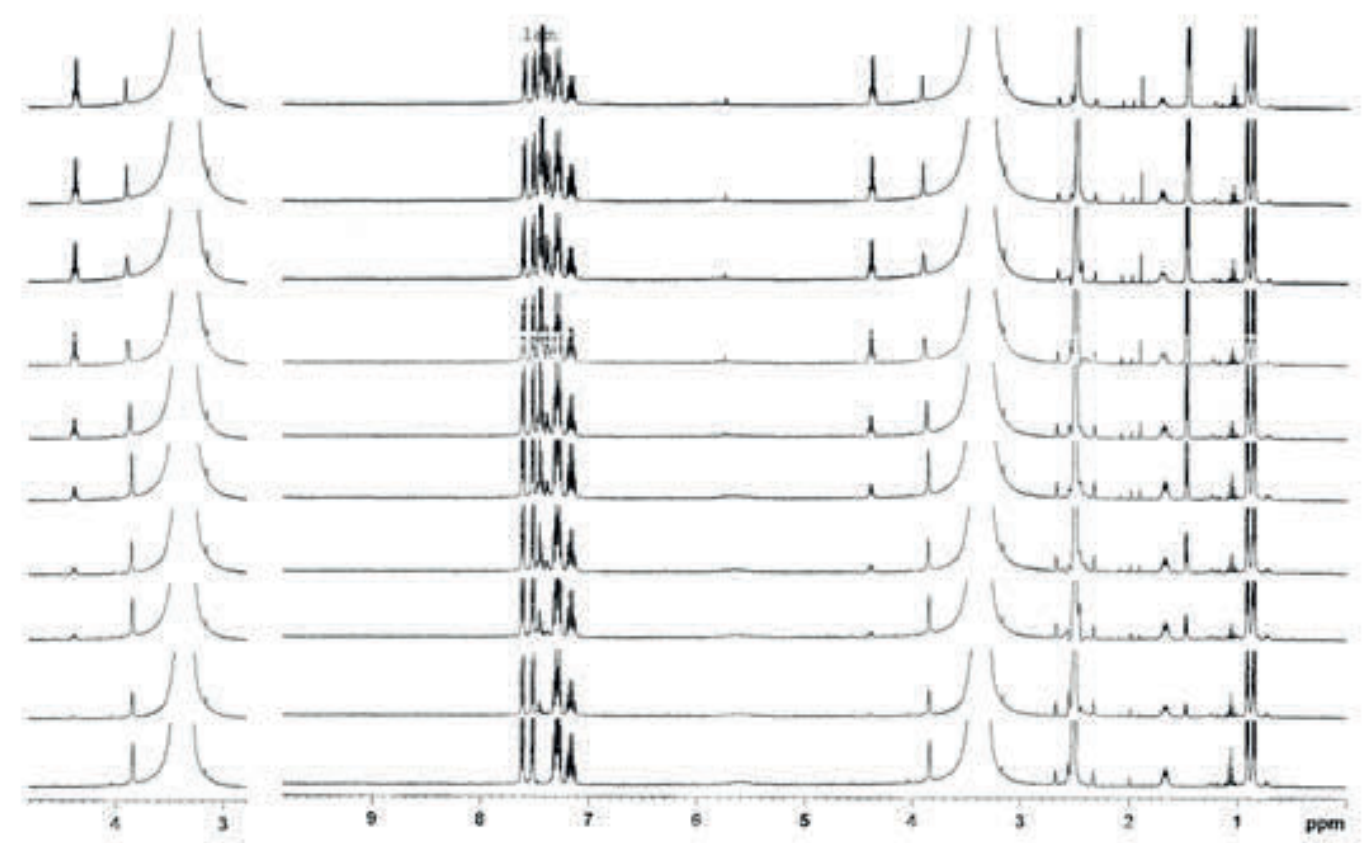

Figure 4. Shifts in ${ }^{1} \mathrm{H}$ NMR spectra of Tripodal Receptor 2 with a constant concentration of $1 \times 10^{-}$ ${ }^{3} \mathrm{M}$ by the addition of increasing $(0.2,0.3,0.7,1.0,2.0,3.0,4.0,5.0,6.0$ fold) $(S)$-AM1 (right ); An expanded part of this spectrum between 3.0 and $4.9 \mathrm{ppm}$ (left).

It is hard to postulate a rationale for the discrimination of AM1 and AM2 salts by receptor 1. However, it may be possible to propose that the methyl group in receptor $\mathbf{1}$ has a better orientation to interact with $S$ enantiomer of AM1, but some show with $R$ enantiomer of AM2. The lower discrimination observed for $\mathbf{2 , 3}$ and $\mathbf{5}$ may be ascribed to the fact that isopropyl, isobutyl and phenyl group is too bulky to have favorable interactions with one of enantiomers of both salts. The phenyl group in receptor $\mathbf{4}$ is expected to be more flexible compared with one in $\mathbf{5}$ and therefore it is likely to provide a better binding site for the $R$ enantiomer of AM1 via $\pi-\pi$ interactions where this would be not possible with AM2, probably due to the larger naphthyl group. 
Table 2. Enantiomeric recognition studies of tripodal receptors 1-5 towards organic ammonium salts in DMSO- $d_{6}$ collected at $25 \pm 0.1{ }^{\circ} \mathrm{C}$.

\begin{tabular}{lllll}
\hline $\begin{array}{l}\text { Tripodal } \\
\text { Receptor }\end{array}$ & Cation & $\boldsymbol{K}\left(\mathbf{M}^{-1}\right)$ & $\boldsymbol{K}_{\mathbf{R}} / \boldsymbol{K}_{\mathbf{S}}$ & $\begin{array}{l}\mathbf{E R F}^{37} \\
\mathbf{\%}\end{array}$ \\
\hline $\mathbf{1}$ & $(R)$-AM1 & $242.81 \pm 1.52$ & 0.48 & $34(\mathrm{~S})$ \\
& $(S)$-AM1 & $501.33 \pm 3.95$ & & \\
& $(R)-\mathrm{AM} 2$ & $643.92 \pm 5.03$ & 2.10 & $36(\mathrm{R})$ \\
$\mathbf{2}$ & $(S)$-AM2 & $305.91 \pm 1.30$ & & \\
& $(R)-\mathrm{AM} 1$ & $107.24 \pm 0.20$ & 1.09 & $4(\mathrm{R})$ \\
& $(S)$-AM1 & $97.92 \pm 0.40$ & & \\
& $(R)-\mathrm{AM} 2$ & $100.11 \pm 0.60$ & 0.93 & $4(\mathrm{~S})$ \\
$\mathbf{3}$ & $(S)$-AM2 & $107.62 \pm 0.41$ & & \\
& $(R)-\mathrm{AM} 1$ & $\mathrm{nd}$ & & --- \\
& $(S)-\mathrm{AM} 1$ & $62.84 \pm 0.32$ & & \\
& $(R)-\mathrm{AM} 2$ & $126.91 \pm 0.88$ & 1.19 & $8(\mathrm{R})$ \\
& $(S)-\mathrm{AM} 2$ & $106.42 \pm 0.85$ & & \\
$\mathbf{4}$ & $(R)-\mathrm{AM} 1$ & $243.97 \pm 0.61$ & 3.36 & $54(\mathrm{R})$ \\
& $(S)-\mathrm{AM} 1$ & $72.58 \pm 0.25$ & & \\
& $(R)-\mathrm{AM} 2$ & $43.10 \pm 0.07$ & 0.86 & $8(\mathrm{~S})$ \\
& $(S)-\mathrm{AM} 2$ & $49.93 \pm 0.82$ & & \\
& $(R)-\mathrm{AM} 1$ & $\mathrm{nd}$ & & --- \\
& $(S)-\mathrm{AM} 1$ & $61.82 \pm 0.16$ & & \\
& $(R)-\mathrm{AM} 2$ & $56.25 \pm 0.11$ & 1.22 & $10(\mathrm{R})$ \\
& $(S)-\mathrm{AM} 2$ & $45.92 \pm 0.14$ & & \\
\hline
\end{tabular}

*AM1: PhenylethylammoniumperchlorateAM2: Naphthylethylammoniumperchlorate

\section{Conclusions}

The paper reports the synthesis of tripodal amides receptors under microwave irradiation and the measurements of their binding properties with anions and cations by ${ }^{1} \mathrm{H}$ NMR titration. The synthesis is too facile since it involves a direct reaction of amine with carboxylic acid with requirement for a coupling agent or catalyst. The binding results indicate that all tripodal receptors possess high affinity for dihydrogenphosphate, benzoate and acetate anions. Moreover, the results obtained regarding to these receptors indicated that they can discriminate between the enantiomers of AM1 and AM2 salts. The results demonstrate that electrostatic interaction, hydrogen bonding, receptor cavity and rigidity, preorganization of binding sites of receptors and the nature of anions and cations play essential roles in the recognition process. The findings are relevant to understand 
the biochemical processes in livings and also may be used to develop systems in material science such as sensors.

\section{Experimental Section}

General information. Melting points were determined with a GALLENKAMP Model apparatus with open capillaries. Infrared spectra were recorded on a MIDAC-FTIR Model 1700 spectrometer. Elemental analyses were obtained with CARLO-ERBA Model 1108 apparatus. Optical rotations were taken on a Perkin-Elmer 341 Model polarimeter. ${ }^{1} \mathrm{H}(400 \mathrm{MHz}),{ }^{13} \mathrm{C}(100 \mathrm{MHz})$ and 2D NMR (DEPT, COSY, HMQC) spectra were recorded on a BRUKER AV400 NMR spectrometer in the indicated solvents. Chemical shifts are expressed in part per million $(\delta)$ using residual solvent protons as internal standards. Mass spectrometry analysis was performed on an autoflex III MALDI-TOF/TOF-MS system (Bruker Daltonics, Bremen, Germany). The START labstation (Milestone labstation for microwave enhanced chemistry) was used for synthesis of chiral tripodal receptors.

\section{Synthesis of the Tripodal Receptors}

In order to improve efficiency and reduce waste production; the microwaves offer mild methods to prepare tripodal receptor 1-5 directly from non-activated carboxylic acids and amines in the absences of coupling reagent and solvents. The reaction conditions (temperature, time and power) for the synthesis of tripodal receptors were optimized under microwave condition. For each tripodal receptor; a power of $1000 \mathrm{~W}$, time of 40 minutes, atmospheric pressure and $150{ }^{\circ} \mathrm{C}$ were found to be most suitable conditions for the highest conversion. Also, 2-3 drops of water is required to improve the conversion.

Table 3. Reaction of (S)-(-)-2-amino-3-methyl-1,1-diphenyl-1-butanol with nitrilotriacetic acid at $150{ }^{\circ} \mathrm{C}$ under microwave condition

\begin{tabular}{llll}
$\begin{array}{l}\text { R. Time } \\
(\text { min.) }\end{array}$ & Power $(\mathbf{W})$ & T $\left({ }^{\circ} \mathbf{C}\right)^{\mathbf{a}}$ & Yields (\%) \\
\hline 30 & 600 & $150(52-54)^{\mathrm{a}}$ & n.r. \\
40 & 800 & $150(76-77)^{\mathrm{a}}$ & n.r. \\
40 & 900 & $150(83-84)^{\mathrm{a}}$ & n.r. \\
40 & 800 & $150(72)^{\mathrm{a}}$ & n.r. \\
40 & 900 & $150(85)^{\mathrm{a}}$ & n.r ${ }^{\mathrm{b}}$
\end{tabular}




$\begin{array}{cccc}20 & 1000 & 150(106)^{\mathrm{a}} & 60^{\mathrm{b}} \\ 30 & 1000 & 150(107)^{\mathrm{a}} & 85 \\ 40 & 1000 & 150(107)^{\mathrm{a}} & 92 \\ 50 & 100 & 150(107)^{\mathrm{a}} & 91\end{array}$

${ }^{a}$ Maximum internal temperatures; n.r.: no reaction. ${ }^{\text {b2-3 }}$ drop of water was added the reaction medium

Tripodal Receptor 1. Nitrilotriacetic acid (76.4 mg, $0.4 \mathrm{mmol})$ and (270 mg, $1.2 \mathrm{mmol})(S)-2-$ amino-1,1-diphenyl-1-propanol were activated by microwave irradiation. The crude product was washed with cold ether to obtain 1 as a white crystalline (305 mg, 93\%). Mp.: 101-103 ${ }^{\circ} \mathrm{C},[\alpha]_{\mathrm{D}}{ }^{25}$ $=+8.3$ (c 1.0, DMSO); MALDI-TOF MS: $m / z 926.85(\mathrm{M}+\mathrm{Ag})^{+} ; \mathrm{IR}(\mathrm{KBr}) \vee 3394(\mathrm{OH}), 3263$ (NH), 3059.3027 (Ar-H), 1636 (amide first band), 1534 (amide second band), ${ }^{1} \mathrm{H}$ NMR (400 MHz, DMSO- $\left.d_{6}\right): \delta 0.95(\mathrm{~d}, 9 \mathrm{H}, J 6.4 \mathrm{~Hz}), 3.28(\mathrm{~s}, 6 \mathrm{H}), 3.40-3.80(\mathrm{bs}, 6 \mathrm{H}, \mathrm{NH}$ and OH overlap DMSO$d_{6}$ water, probably), 4.25 (q, 3H, $J$ 6.4Hz), 7.14-7.63 (m, 30H). ${ }^{13} \mathrm{C}$ NMR (100 MHz, DMSO- $\left.d_{6}\right): \delta$ $15.62\left(\mathrm{CH}_{3}\right), 52.55(\mathrm{CH}), 58.04\left(\mathrm{CH}_{2}\right), 78.77(-\mathrm{C}-), 125.88(\mathrm{Ar}-\mathrm{CH}), 126.35(\mathrm{Ar}-\mathrm{CH}), 126.84$ (Ar$\mathrm{CH}), 127.20$ (Ar-CH), $128.44(\mathrm{Ar}-\mathrm{CH}), 128.75$ (Ar-CH), 145.79 (Ar-C), 145.97 (Ar-C), $169.92(\mathrm{C}$ $=\mathrm{O})$. Anal.Calcd for $\mathrm{C}_{51} \mathrm{H}_{54} \mathrm{~N}_{4} \mathrm{O}_{6}: \mathrm{C}, 74.80, \mathrm{~N}, 6.84, \mathrm{H}, 6.65$. Found: $\mathrm{C}, 74.77, \mathrm{~N}, 6.81, \mathrm{H}, 6.68$.

Tripodal Receptor 2. Nitrilotriacetic acid $(53.0 \mathrm{mg}, 0.28 \mathrm{mmol})$ and $(S)-(-)-2$-amino-3-methyl1,1-diphenyl-1-butanol (212 $\mathrm{mg}, 0.83 \mathrm{mmol})$ were activated by microwave irradiation. The crude product was obtained as white crystalline after washing with cold ether (230 mg, 92\%).Mp.: 203$20{ }^{\circ} \mathrm{C},[\alpha]_{\mathrm{D}^{27}}=-4.2(c 1.0, \mathrm{MeOH})$; IR (KBr) v $3391(\mathrm{OH}), 3256(\mathrm{~N}-\mathrm{H}), 3059(\mathrm{Ar}-\mathrm{H}), 1629$ (amide first band), 1537 (amide second band), ${ }_{1}^{1} \mathrm{H}$ NMR (400 MHz, DMSO- $d_{6}$ ): $\delta 0.89$ (d, 9H, $J 6.8 \mathrm{~Hz}$ ), $0.92(\mathrm{~d}, 9 \mathrm{H}, J 7.0 \mathrm{~Hz}), 1.65-1.76(\mathrm{~m}, 3 \mathrm{H}), 3.31(\mathrm{~s}, 6 \mathrm{H}), 3.7-3.90(\mathrm{bs}, 6 \mathrm{H}, \mathrm{NH}$ and $\mathrm{OH}$ overlap DMSO- $d_{6}$ water, probably), $3.99(\mathrm{~m}, 6 \mathrm{H}), 7.12-7.64(\mathrm{~m}, 30 \mathrm{H}) .{ }^{13} \mathrm{C}$ NMR $\left(100 \mathrm{MHz}, \mathrm{DMSO}-d_{6}\right): \delta$ $17.05\left(\mathrm{CH}_{3}\right), 23.08\left(\mathrm{CH}_{3}\right), 27.91(\mathrm{CH}), 58.54\left(\mathrm{CH}_{2}\right), 60.48(\mathrm{CH}), 80.92(\mathrm{C}), 125.74(\mathrm{Ar}-\mathrm{C}), 126.44$ (Ar-C), 126.51 (Ar-C), 126.81 (Ar-C), 128.36 (Ar-C), 128.57 (Ar-C), 146.62 (Ar-C), 147.63 (ArC), $173.78(\mathrm{C}=\mathrm{O})$. Anal.Calcd for $\mathrm{C}_{57} \mathrm{H}_{66} \mathrm{~N}_{4} \mathrm{O}_{6}: \mathrm{C}, 75.80 ; \mathrm{N}, 6.20 ; \mathrm{H}, 7.37$. Found: C, 75.75; N, $6.15 ; \mathrm{H}, 7.42$.

Tripodal Receptor 3. Nitrilotriacetic acid (50.0 mg, $0.26 \mathrm{mmol})$ and (210 $\mathrm{mg}, 0.78 \mathrm{mmol})(S)-(-$ )-2-amino-4-methyl-1,1-diphenyl-1-pentanol were activated by microwave irradiation. The crude product was washed with cold ether, to obtain 3 as a white crystalline (220 mg, 90\%). Mp.: 229$230{ }^{\circ} \mathrm{C},[\alpha]_{\mathrm{D}}^{25}=-46.5(c$ 1.0, DMSO); IR (KBr) $v 3394(\mathrm{OH}), 3258(\mathrm{NH}), 3059(\mathrm{Ar}-\mathrm{H}), 2957(\mathrm{RH})$, 1649 (amide first band), 1586 (amide second band). ${ }^{1} \mathrm{H}$ NMR (400 MHz, DMSO- $d_{6}$ ): $\delta 0.78$ (d, 9H, $J 6.4 \mathrm{~Hz}), 0.83$ (d, 9H, $J 6.0 \mathrm{~Hz}), 0.96-1.02(\mathrm{~m}, 3 \mathrm{H}), 1.38-1.44(\mathrm{~m}, 3 \mathrm{H}), 1.71-1.74(\mathrm{~m}, 3 \mathrm{H})$, $3.29(\mathrm{~s}, 9 \mathrm{H}), 3.40-3.80\left(\mathrm{bs}, 3 \mathrm{H}, \mathrm{NH}\right.$ or $\mathrm{OH}$ overlap DMSO- $d_{6}$ water, probably), 4.10 (d, $3 \mathrm{H}, J=$ 10.1), 7.15-7.64 (m, 30H). ${ }^{13} \mathrm{C}$ NMR (100 MHz, DMSO- $\left.d_{6}\right): \delta 21.69\left(\mathrm{CH}_{3}\right), 24.40(\mathrm{CH}), 24.43$ 
$\left(\mathrm{CH}_{3}\right)$, $39.15\left(\mathrm{CH}_{2}\right.$, from DEPT 135), $55.19(\mathrm{CH}), 58.22\left(\mathrm{CH}_{2}\right), 79.62(-\mathrm{C}-), 125.92(\mathrm{Ar}-\mathrm{CH})$, 126.49 (Ar-CH), 126.90 (Ar-CH), 127.21 (Ar-CH), 128.43 (Ar-CH), 128.76 (Ar-CH), 145.70 (ArC), 145.98 (Ar-C), $172.14(\mathrm{C}=\mathrm{O})$. Anal.Calcd for $\mathrm{C}_{60} \mathrm{H}_{72} \mathrm{~N}_{4} \mathrm{O}_{6}: \mathrm{C}, 76.24, \mathrm{~N}, 5.93, \mathrm{H}, 7.68$. Found: C, 76.19, N, 5.95, H, 7.66.

Tripodal Receptor 4. Nitrilotriacetic acid (73.0 mg, $0.38 \mathrm{mmol})$ and (348 $\mathrm{mg}, 1.15 \mathrm{mmol})(S)-(-$ )-2-amino-1,1,3-triphenyl-1-propanol were activated by irradiation microwave. The crude product was dissolved in methanol to take it and the solvent was removed by a rotary evaporator. The resulting product was crystallized in mixture of ethyl acetate-methanol (2:1), which was then filtered and washed with diethyl ether to obtain 4 as a white crystalline (360 mg, 90\%). Mp.: 205$208^{\circ} \mathrm{C},[\alpha]_{\mathrm{D}^{20}}=-7.8\left(c 1.0\right.$, DMSO); MALDI-TOF MS: $m / z 1069.98(\mathrm{M}+\mathrm{Na})^{+}$, IR $(\mathrm{KBr}) v 3388$ (OH), $3280(\mathrm{NH}), 3061,3029$ (Ar-H), 1638 (amide first band), 1540 (amide second band), ${ }^{1} \mathrm{H}$ NMR (400 MHz, DMSO- $\left.d_{6}\right)$ : 2.42-2.63 (m, 6H), 3.32 (s, 6H), 3.60-4.1(bs, 6H, NH and OH overlap DMSO- $d_{6}$ water, probably), $4.23(\mathrm{~m}, 3 \mathrm{H}), 7.17-7.68(\mathrm{~m}, 45 \mathrm{H}) .{ }^{13} \mathrm{C}$ NMR (100 MHz, DMSO- $\left.d_{6}\right)$ : $\delta 37.15\left(\mathrm{CH}_{2}\right), 58.26\left(\mathrm{CH}_{2}\right), 58.92(\mathrm{CH}), 79.95(\mathrm{C}), 105.00$ (Ar-C), 125.94 (Ar-C), 126.50 (Ar-C), 126.78 (Ar-C), 126.92 (Ar-C), 128.53 (Ar-C), 128.62 (Ar-C), 128.66 (Ar-C), 129.62 (Ar-C), 140.00 (Ar-C), 146.32 (Ar-C), 146.70 (Ar-C), $174.19(\mathrm{C}=\mathrm{O})$. Anal.Calcd. for $\mathrm{C}_{69} \mathrm{H}_{66} \mathrm{~N}_{4} \mathrm{O}_{6}$ : C, 79.13, N, 5.35, H, 6.35. Found: C, 79.10, N, 5.38, H, 6.32.

Tripodal Receptor 5. Nitrilotriacetic acid (50.0 mg, $0.26 \mathrm{mmol})$ and (227 $\mathrm{mg}, 0.78 \mathrm{mmol})(S)-(-$ )-2-amino-1,1,2-triphenyletanol were activated by irradiation microwave. The crude product was washed with cold ether to obtain 5 as a white crystalline $(225 \mathrm{mg}, 90 \%)$. Mp.: $186-188{ }^{\circ} \mathrm{C},[\alpha]_{\mathrm{D}}{ }^{25}$ $=-157.5$ (c 1.0, DMSO); MALDI-TOF MS: $m / z 1005(\mathrm{M}+\mathrm{H})^{+}, \mathrm{IR}(\mathrm{KBr}) \vee 3388(\mathrm{OH}), 3237$ (NH), 3060, 3031 (Ar-H), 1630 (amide first band), 1537 (amide second band). ${ }^{1} \mathrm{H}$ NMR (400 MHz, DMSO- $\left.d_{6}\right): 3.31(\mathrm{~s}, 6 \mathrm{H}), 3.70-4.70\left(\mathrm{bs}, 6 \mathrm{H}, \mathrm{NH}\right.$ and $\mathrm{OH}$ overlap DMSO- $d_{6}$ water, probably), 5.20 (s, 3H), 6.96-7.79 (m, 45H). ${ }^{13} \mathrm{C}$ NMR (100 MHz, DMSO- $\left.d_{6}\right): \delta 58.37\left(\mathrm{CH}_{2}\right), 61.11(\mathrm{CH}), 80.10$ (-C-), 126.30 (Ar-CH), 126.38 (Ar-CH), 126.98 (Ar-CH), 127.14 (Ar-CH), 127.28 (Ar-CH), 127.46 (Ar-CH), 127.66 (Ar-CH), 128.60 (Ar-CH), 129.75 (Ar-CH), 140.19 (Ar-C), 145.51 (ArC), $146.68\left(\right.$ Ar-C), $171.21(\mathrm{C}=\mathrm{O})$. Anal.Calcd for $\mathrm{C}_{66} \mathrm{H}_{60} \mathrm{~N}_{4} \mathrm{O}_{6}: \mathrm{C}, 78.87, \mathrm{~N}, 5.57, \mathrm{H}, 6.02$. Found: C, 78.81, N, 5.63, H, 6:04.

\section{${ }^{1}$ H NMR Titration}

The dissociation constants ( $\left.K_{\text {diss }}\right)$ between each host and guest were calculated from the change in $\delta$ values in host against increasing guest concentration in the presence of constant host concentration by non-linear least-squares fitting method ${ }^{38}$ using Graph Pad Pris 4 pocket programme using Equation(4), derived from (1-3). 


$$
\begin{gathered}
\text { Host }+ \text { Guest } \underset{k_{-1}}{\stackrel{k_{1}}{\rightleftharpoons} \text { Host.Guest }} \\
K_{\text {diss }}=\frac{k_{-1}}{k_{1}}=\frac{[\text { Host }] \text {. [guest }]}{[\text { Host.Guest }]} \\
{[\text { Guest }]_{\text {tot. }}=[\text { Guest }]_{\text {free }}+[\text { Guest }]_{\text {complex }}} \\
\delta_{\text {obs }}=\frac{\left(\delta_{0} K_{\text {diss }} \cdot+\delta_{\text {max }}[\text { Guest }]_{\text {tot. }}\right)}{\left(K_{\text {diss. }}+[\text { Guest }]_{\text {tot. }}\right)}
\end{gathered}
$$

Where $K_{\text {diss }}$ is the dissociation constant between a host and a guest, $\delta_{0}$ is the chemical shift in specific hydrogen of a guest in the absence of a host, $\delta_{\text {obs }}$ is the observed chemical shift in the same hydrogen in the presence of a host and $\delta_{\max }$ is the maximum chemical shift achieved in the presence of a host.

The concentration of tripodal receptors was kept constant at $1 \times 10^{-3} \mathrm{M}$ in DMSO- $d_{6}$ collected at 25 $\pm 0.1{ }^{\circ} \mathrm{C}$. The binding constants were calculated from the chemical shifts in the ${ }^{1} \mathrm{H}$ NMR peak of $\mathrm{CH}$ (asymmetrical methine hydrogen) in the tripodal receptors against the addition of various concentrations (0-6 mM) of tetrabuthylammonium form of anions and chiral organic ammonium salts. The most regular change in these structures was observed in the - $\mathrm{CH}$ (asymmetrical methine) hydrogen since $-\mathrm{NH}$ signals of the amide group overlap with those of aromatic groups in this tripodal receptor. Therefore, the signal of $-\mathrm{CH}$ was monitored to determine complexation parameters for anions and cations with tripodal receptors.

\section{Acknowledgements}

We would like to thank The Scientific and Technological Research Council of Turkey

(TUBITAK) for financially supporting this research (Project No: $109 \mathrm{~T} 787$ ). We are grateful to Dr. Necmettin Pirincioglu (Dicle University) for their invaluable contribution.

\section{Supplementary Material Available}

Detailed NMR, MALDI-TOF/TOF-MS and IR spectra are given in the Supplementary Data file.

\section{References}

1. Diamond, D.; Nolan, K.Anal. Chem. 2001,73, 22A-29A

http://pubs.acs.org/doi/abs/10.1021/ac012376g 
2. Ludwig, R.; Dzung, N.T.K. Sensors 2002, 2, 397-416.

http://www.mdpi.com/1424-8220/2/10/397

3. Beer, P.D.; Gale, P.A.Angew. Chem. Int. Ed. Engl.2001,40, 486-516. http://www.ncbi.nlm.nih.gov/pubmed/11180358

4. Antonisse, M.M.G.; Reinhoudt, D.N. Electroanalysis 1999, 11, 1035-1048. http://onlinelibrary.wiley.com/doi/10.1002/(SICI)1521-4109(199910)

5. Antonisse, M.M.G.; Reinhoudt, D.N. Chem. Commun. 1998, 443-448. http://pubs.rsc.org/en/Content/ArticleLanding/1998/CC/a707529d\#!divAbstract

6. Kuswandi, B.; Nuriman, N/a.; Verboom, W.; Reinhoudt, D.N.Sensors 2006, 6, 978-1017. http://www.mdpi.com/1424-8220/6/8/978

7. Reinoso-Garcia, M.M.; Dijkman, A.; Verboom, W.; Reinhoudt, D.N.; Malinoswka, E.; Wojciechowska, D.; Pietrzak, M.; Selucky, P. Eur. J. Org.Chem. 2005, 10,2131-2138. http://onlinelibrary.wiley.com/doi/10.1002/ejoc.200500002/abstract

8. (a) Kim,Y. K.; Ha, J.; Cha, G.S.; Ahn, K.H. Korean Chem. Soc. 2002, 23, 1420-1424. http://www.koreascience.or.kr/article/ArticleFullRecord.jsp?cn=JCGMCS_2002_v23n10_14 20 (b) Kim, S.G.; Kim, K.H.; Jung, J.; Shin, S.K.; Ahn, K.H. J. Am. Chem. Soc. 2002, 124, 591-596. http://pubs.acs.org/doi/pdf/10.1021/ja0119696

9. Sasaki, S.; Ozawa, S.; Citterio, D.; Iwasawa, N.; Suzuki, K. Anal. Sci. 2001, 17, 1659- 1661. https://www.jstage.jst.go.jp/article/analscisp/17icas/0/17icas_0_i1659/article

10. Reinoso-Garcia, M.M.; Janczewski, D.; Reinhoudt, D.N.; Verboom, W., Malinoswka, E.; Pietrzak, M.; Hill, D.; Baca, J.; Gruner, B.; Selucky, P.; Gruttner, C. New J. Chem. 2006, 30, $1480-1492$. http://pubs.rsc.org/en/Content/ArticleLanding/2006/NJ/b600412a\#!divAbstract

11. Schmuck, C.; Schwegmann, M. Org. Biomol. Chem. 2006, 4, 836-838. http://pubs.rsc.org/en/content/articlehtml/2006/ob/b516019g?page=search

12. Wei, L.H.; He, Y.B.; Wu, J.L.; Qin, H.J.; Xu, K.X.; Meng, L.Z. Chin. J. Chem.2005, 23, 608612.

http://onlinelibrary.wiley.com/doi/10.1002/cjoc.200590608/abstract

13. Niikura, K., Bisson, A.P.; Anslyn, E.V.J. Chem. Soc. Perkin Trans. 1999, 2, 1111-1114. http://pubs.rsc.org/en/content/articlelanding/1999/p2/a901180c\#!divAbstract

14. Wiskur, S.L.; Anslyn, E.V. J. Am. Chem. Soc. 2001, 123, 10109-10110. http://pubs.acs.org/doi/abs/10.1021/ja011800s

15. Sato, K.; Arai, S.; Yamagishi, T. Tetrahedron Lett. 1999, 40, 5219-5222. http://www.sciencedirect.com/science/article/pii/S0040403999009429

16. Ballester, P.; Costa, A.; Deyâ, P.M.; Vega, M.; Morey, J.; Deslongchamps, G. Tetrahedron Lett.1999,40, 171-174. http://www.sciencedirect.com/science/article/pii/S0040403998800506

17. Fan, A.L.; Hong, H.K., Valiyaveettil, S.; Vittal, J.J. J. Supramol. Chem. 2002, 2, 247-254. http://www.sciencedirect.com/science/article/pii/S1472786203000790 
18. Arunachalam M.; Ghosh, P.Org. Lett. 2010, 12(2), 328-331.

http://pubs.acs.org/doi/abs/10.1021/o19026649

19. Berrocal, M.J.; Cruz, A., Badr, I.H.A.; Bachas, L.G. Anal. Chem. 2000, 72, 5295-5299. http://pubs.acs.org/doi/abs/10.1021/ac000241p

20. Khalafi-Nezhad, A.; Mokhtari, B.; Rad, M.N.S. Tetrahedron Lett. 2003, 44, 7325-7328. http://www.sciencedirect.com/science/article/pii/S0040403903018665

21. Ozturk, G.; Çolak, M.; Toğrul, M. J. of Incl. Phenom. And Macrocyc. Chem. 2010, 68(1), 4954.

http://link.springer.com/article/10.1007/s10847-009-9731-6

22. Varma, R.S. Green Chem. 1999, 1, 43-55.

http://pubs.rsc.org/en/content/articlehtml/1999/gc/a808223e

23. Loupy, A.; Petit, A.; Hamelin, J.; Texier-Boullet, F.; Jacquault, P.; Mathe, D. Synthesis 1998, 1213-1234.

https://www.thieme-connect.com/products/ejournals/abstract/10.1055/s-1998-6083.

24. Loupy, A.: Microwaves in organic synthesis; Wiley-VCH: Weinheim, 2002.

http://microwave.icpf.cas.cz/publications/MP-2006.pdf

25. Perreux, L.; Loupy, A.; Volatran, F. Tetrahedron 2002, 58, 2155-2162. http://www.sciencedirect.com/science/article/pii/S0040402002000856

26. Perreux, L.; Loupy, A.; Delmotte, M. Tetrahedron 2003, 59, 2185-2189. http://www.sciencedirect.com/science/article/pii/S0040402003001510.

27. Gelens, E.; Smeets, L.; Sliedregt, L.A.J.M.; van Steen, B.J.; Kruse, C.G.; Leurs, R.; Orru, R.V.A. Tetrahedron Lett. 2005, 46, 3751-3754.

http://www.sciencedirect.com/science/article/pii/S0040403905006660

28. de la Hoz, A.; Diaz-Ortiz, A.; Moreno, A.Chem. Soc. Rev. 2005, 34, 164-168. http://pubs.rsc.org/en/content/articlelanding/cs/2005/b411438h\#!divAbstract

29. Ferroud, D.; Godart, M.; Ung, S.; Borderies, H.; Guy, A. Tetrahedron Lett. 2008, 49, 30043008 .

http://www.sciencedirect.com/science/article/pii/S0040403908004292

30. Job, P.Ann. Chim. 1928,9, 113-203.

http://www.sciepub.com/reference/42964

31. Connors, K.A. Binding Constants; Wiley:New York, 1987.

http://www.amazon.com/Binding-Constants-Measurement-MolecularStability/dp/0471830836

32. Fielding, L. Tetrahedron 2000, 56, 6151-6170. http://www.sciencedirect.com/science/article/pii/S0040402000004920

33. Ozturk, G.; Colak, M.; Togrul, M. J. Incl. Phenom. Macrocycl. Chem. 2010, 68, 49-54. http://link.springer.com/article/10.1007/s10847-009-9731-6

34. Pandian, S.; Kang J. Bull. Korean Chem. Soc. 2014, 35, 2025-2028. https://scholar.google.com.tr/scholar?q=Bull. + Korean + Chem. + Soc. $+2014 \% 2 \mathrm{C}+35 \% 2 \mathrm{C}+202$ $5-2028 \&$ btnG $=\& h \mathrm{hl}=\operatorname{tr} \&$ as_sdt $=0 \% 2 \mathrm{C} 5$ 
35. Amendola,V.; Esteban-Goä Mez, D.; Fabbrızzı, L.; Licchellı, M. Acc. Chem. Res. 2006, 39, 343-353.

http://pubs.acs.org/doi/abs/10.1021/ar0501951.

36. Wei, L. H.; He, Y. B.; Wu, J.L.; Qin, H.J.; Xu, K. X.; Meng, L. Z. Chin. J. Chem. 2005, 23, 608-612.

http://onlinelibrary.wiley.com/doi/10.1002/cjoc.200590608/abstract

37. Sunkur, M.; Baris, D.; Hosgoren, H.; Togrul, M. J. Org. Chem. 2008, 73, 2570-2575. http://pubs.acs.org/doi/abs/10.1021/jo702210c

38. Macomber. R.S. J. Chem. Educ. 1992, 69(5), 375-382.

http://pubs.acs.org/doi/abs/10.1021/ed069p375. 